UNITED STATES DEPARTMENT OF COMMERCE

Alexander B. Trowbridge, Acting Secretary

NATIONAL BUREAU OF STANDARDS • A. V. Astin, Director

\title{
Ḃibliography Of Low Energy
}

\section{Electron Collision Cross Section Data}

\author{
L. J. Kieffer \\ Laboratory Astrophysics Division \\ Institute for Basic Standards \\ National Bureau of Standards \\ Boulder, Colorado 80302
}

National Bureau of Standards Miscellaneous Publication 289

Issued March 10, 1967

For Sale by the Superintendent of Documents, U.S. Government Printing Office

Washington, D. C., 20402 - Price 50 cents 